DOI: $10.22616 /$ j.balticsurveying.2018.002

\title{
ANALYSIS OF EXISTING SPATIAL INFORMATION SYSTEMS IN TERMS OF ITS USE FOR THE RENEWAL AND REVITALIZATION OF RURAL AREAS
}

\author{
Mateusz Ciski, Krzysztof Rzasa, Marek Ogryzek \\ Institute of Geography and Land Management \\ University of Warmia and Mazury in Olsztyn
}

\begin{abstract}
Revitalization is a set of urban and planning activities, coordinated by local self-government administration, aim of which is a social, architectural, planning and economical advantageous transformation of the specific area of the municipality, being in a state of crisis resulting from economic and social factors. Whereas, the renewal of the countryside is understood as shaping the living conditions of people in rural areas, with the local community as an animator and subject. The combination of revitalization and renewal of rural areas is a particularly important and urgent task, connected with rural and architectural chaos, decline of cultural context and local tradition. The aim of the article is to examine information needs for the renewal and revitalization of rural areas, and the possibilities of satisfying these needs using available spatial information systems.

The first part of the paper contains an analysis of information needs in the field of renewal and revitalization of rural areas, created on the basis of literature and valid legal provisions. The created information resource illustrates the scope of data necessary for proper planning of renewal and revitalization of rural areas.

In the second part, specific information needs were compared with the capabilities of existing spatial information systems. The possibility of obtaining free of expense information necessary for renewal and revitalization of rural areas was analysed. Systems which may be useful in the implementation of related activities are also indicated.

Key words: spatial information systems, revitalization, renewal of rural areas, data sources.
\end{abstract}

\section{Introduction}

In accordance with the Revitalisation Act of 9 October 2015, revitalisation is a process for deriving from a state of crisis in degraded areas, carried out in a comprehensive manner through integrated activities for the local community, space and economy, geographically concentrated and led by revitalisation stakeholders based on a municipal regeneration programme. According to the guidelines of Ministry for Regional Development on programming activities related to housing, the process of revitalisation is comprehensive, coordinated, long-term and carried out on a specific area of spatial transformation. It is technical, social and economic, initiated by the local government in order to take an area out of a state of crisis by giving a new functional quality and creating conditions to it for its development on the basis of the specific local determinants (Narodowe... 2008). The Scientific Committee of the Institute of Urban Development defined revitalisation as a coordinated process conducted jointly by the local government, the local community and other participants as part of development policy with a view to preventing the degradation of the urban space and crisis phenomena, boosting development and quality changes by increasing social and economic activity, improving the environment and the protection of national heritage, while also maintaining the principles of sustainable development (Rewitalizacja... 2017).

Revitalization nowadays is a serious challenge for local authorities. We can no longer afford misplaced, individual projects and wasting of public money, including European funds for revitalization. Actually, there are no municipalities in Poland today, where there are no areas concentrating negative social and infrastructural phenomena (Kołacz, Wielgus, 2015).

Revitalization includes the optimal use of specific conditions of a given area and strengthening its local potentials (including cultural potential), and is a long-term process led by stakeholders of this process (including entrepreneurs, non-governmental organizations, property owners, public authorities, etc.), mainly in cooperation with the local community. Activities to support revitalization processes are carried out in a coherent manner: internally (individual actions between each other) and 
externally (with local sectorial policies, e.g. transport, energy; with goals and directions resulting from strategic and planning documents).

In the process of revitalization, the proper determination of the degraded area and the area of revitalization is particularly important. In accordance with the Revitalisation Act of 9 October 2015, degraded area is the area of the municipality in crisis state due to the concentration of negative social phenomena, in particular unemployment, poverty, crime, low education or social capital, as well as insufficient participation in public and cultural life. The degraded area must also be characterized by at least one of the following negative phenomena: economic, environmental, spatial and functional, technical.

An area covering all or part of a degraded area, characterized by a high concentration of negative phenomena, on which, due to significant importance for local development, the municipality intends to carry out revitalization process, is designated as a revitalization area.

The concept of "renewal of rural areas" has been functioning in Poland since 1997, when Wilczyński, inspired by actions for the development of rural areas in Austria and Germany, initiated the creation of the first regional program of renewal of rural areas in the Opolskie Voivodeship (Wilczyński, 2003). Renewal of rural areas means the planned and implemented by the rural community development process, based on local resources using external support (Wilczyński, 2008). These activities are based on the involvement of citizens motivated by responsibility for the fate of their own surroundings. The most important thing in this noble idea is that the inhabitants of the Polish village themselves should initiate changes in their localities, and together they would strive to improve the quality of life and economic independence. Inhabitants of the village should therefore be both the subject and the driving force for the development of their region, should feel responsible for what they can do for themselves and future generations, caring for the preservation of their identity but without giving up modern technical solutions or ideas used e.g. in EU countries (Wilczyński, 2003). In the renewal of rural areas, development factors (including non-material ones) are launched from the bottom up - of will and for the benefit of residents. Activities falling within the scope of renewal of rural areas should lead to deeper integration of rural societies (among others, through the creation of the Village Renewal Groups by the residents) and to improve economic conditions by shaping entrepreneurial attitudes. The activity of local communities is based on support from the regional level in the form of regional/voivodeship programs of renewal of rural areas (Wilczyński, 2012). Renewal of rural areas is the direction of rural development, combining respect for tradition with the need to look for a place for a village in the changing world. It is process of constant adjustment to social and economic, internal and external changes, that should lead to the overall shaping of the living conditions of rural residents (Idziak, Wilczyński, 2013).

The combination of renewal and revitalization of rural areas is a particularly important and urgent task, connected with rural and architectural chaos, loss of cultural context and tradition of the place, as well as many social problems occurring in rural areas (Biczkowski, Biczkowska, 2017). The aim of the article is to examine information needs in terms of renewal and revitalization of rural areas and the possibilities of meeting them with the use of available spatial information systems.

\section{Methodology of research and materials}

In order to achieve the research goal set in the article, the authors in the first stage analysed in detail the processes of revitalization and renewal of the rural areas. The legal bases of these activities, ministerial guidelines and scientific literature on this subject were analysed. On this basis, the main information needs necessary to implement these processes have been identified. Not all information resources needed and functioning in cities are just as important in rural areas (Cellmer, Źróbek, 2008; Szafraniec, 2012).

When establishing a degraded area, a number of quantitative and descriptive information should be collected, primarily of a social nature, but also: economic, environmental, spatial and functional, and technical. This requires the analysis of negative phenomena in the spheres:

1. social (information on: high unemployment, significant poverty, high crime, low level of education and social capital, insufficient level of participation in public and cultural life)

2. economic (information on: low level of entrepreneurship, poor condition of local enterprises, low economic activity) 
3. environmental (information on: exceeding the environmental quality standards, the presence of waste posing a threat to life, human health or the environment)

4. spatial and functional (information about: insufficient equipment in technical and social infrastructure or its poor technical condition, lack of access to basic services or its poor quality, non-adaptation of urban solutions to the changing functions of the area, low level of communication service, shortage or poor quality of public areas)

5. technical (in particular, degradation of the technical condition of buildings (including housing), and failure of technical solutions enabling effective use of construction facilities, in particular in the field of energy efficiency and environmental protection).

In both analysed activities, social participation is very important. Activities related to renewal of rural areas require the participation of the local community as a factor triggering this process. Therefore, it is necessary to collect data on residents' expectations regarding the local area by carrying out, for example: surveys, tests, standardized and free interviews, debates, public hearings, etc.

As part of the revitalization carried out, it is necessary to examine its links with other strategic and planning documents in the municipality. Therefore, it is necessary to obtain data from: municipality development strategy, study of the conditions and directions of the spatial management or a municipal strategy for solving social problems.

All this information must be spatially referenced and associated with location data - only then it can be the basis for conducting proper analyses. As in all spatially related activities, information should contain: course of borders, location of various objects, structure of use, type and functions of buildings, designation of areas for various purposes, technical infrastructure, communication systems, etc.

After analysing the demand for information, in the second part of the article, the authors analysed the available functioning spatial information systems. The possibility of the user obtaining free of charge information necessary for renewal and revitalization of rural areas was analysed. Systems, which may be useful in the implementation of related activities, are indicated - the next chapter contains the results of these analyses. It became the basis for conclusions from the research carried out in the last part of the article.

\section{Discussions and results}

Spatial data, on which spatial information systems are based, are acquired from many different sources today. The most popular and, at the same time, the most important ones are: satellite images, aerial photographs, terrestrial (stereoscopic) pictures, GPS receivers, automatic measurement stations, geodetic measurements, field work and surveys, maps and plans, state data resources, data resources of various institutions (Zhao, Bryan, King, Song, \& Yu, 2012; Freire \& Painho, 2014; Wei, Hsu, Peng, \& Lee, 2014). The aim of the article is to review available spatial information systems, and more specifically its key element - online databases. All spatial data described in this chapter has been visualized in the ArcMap component of ArcGIS 10.4.1 software, while screenshots from the described spatial information systems come from the corresponding websites.

GEOPORTAL website (geoportal.gov.pl) provides access to current and accurate spatial information, including data on the geographical environment. Thanks to the GEOPORTAL project, implemented by Head Office of Geodesy and Cartography (pol. Główny Urząd Geodezji i Kartografii, GUGiK) spatial information infrastructure services are available electronically not only for selected units of government and local government administration, which create or maintain registers, but also for individual users or other organizational units. WMS browsing services (Web Map Service) is an international standard for sharing spatial data in a raster format. Available through the geoportal.gov.pl service, it consists of a series of maps of the entire country (e.g. topographic map, orthophotomap, numerical terrain model, etc.). WMS services are distributed by municipal or county WMS servers. Figure 1 presents areas threatened by floods, WMS service from Polish Geological Institute, via GEOPORTAL website. 


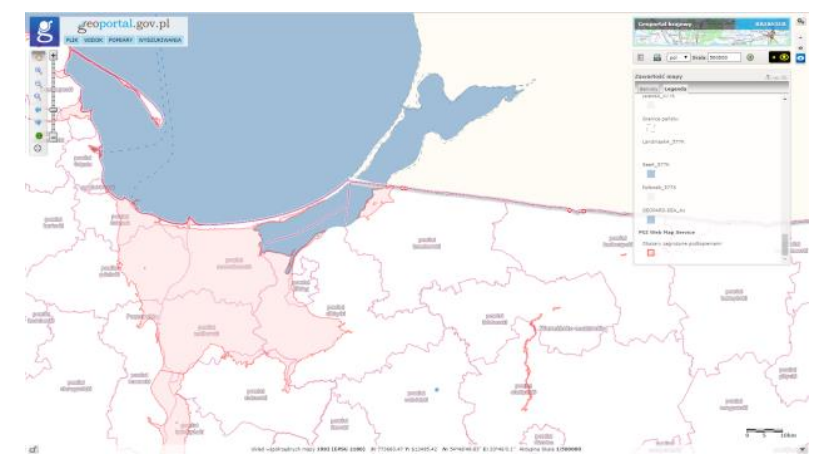

Fig. 1. Areas threatened by floods, Polish Geological Institute

(pol. Państwowy Instytut Geologiczny, PIG), mapy.geoportal.gov.pl/imap/?gpmap=gp0, 17.07.2018

Center for Geodetic and Cartographic Documentation (pol. Centralny Ośrodek Dokumentacji Geodezyjnej i Kartograficznej, CODGiK, codgik.gov.pl) collects, maintains and shares available databases of central geodetic and cartographic resources. 31/12/2017 CODGiK was liquidated and its duties were taken over by GUGiK. CODGiK commissioned by GUGiK maintains the geoportal.gov.pl service in its infrastructure and trades data collected in the central geodetic and cartographic resources. In accordance with the Act on Geodetic and Cartographic Law of May 17, 1989; no fees are charged for sharing data sets of: state register of boundaries and areas of territorial division units of the country (pol. państwowy rejestr granic - PRG), state register of geographical names (pol. państwowy rejestr nazw geograficznych - PRNG), database of general geographic objects (pol. baza danych obiektów ogólnogeograficznych - BDOO), a numeric terrain model with a grid interval of at least $100 \mathrm{~m}$ (NMT_100), index grids for topographic maps and non-standard topographic studies, PL-1992 layout split sheets in scales 1: 1250, 1: 12500 and 1: 5000. Vector data on territorial division - state register of boundaries and areas of territorial division units of the country (PRG) -are available in SHP format and cover the area of the whole country in the scope of boundaries and surfaces of basic units of the three-tier territorial division of the country (i.e. municipalities, counties, voivodeships). The state register of boundaries and areas of territorial division units of the country databases also contain vector data in SHP format with Special Borders, which includes the following boundaries: the area of activity of the head of the civil defence of the voivodeship; Maritime Office; regional water management board; Regional Prosecutor's Office; internal sea waters; exclusive economic zone; technical belt; appellate prosecutor's office; capital police station; National Archives; County Police; squadron of border guards; tax office of large taxpayers; Country Court; marina; voivodeship command of the fire brigade; voivodeship administrative court; the area of activity of the head of the civil defence of the municipality; county fire brigade command; appellate court; border guard institution; regional police command; basic tax office; statistical region; superintendence; census circuit; tax agency; coastal belt; regional directorate of the State Forests; police station; territorial sea of the Republic of Poland. Figure 2 shows municipalities and registration districts of Braniewo county.

As a part of the LPIS project (Land-Parcel Identification System, pol. System Identyfikacji Dziatek Rolnych, which is managed by the Agency for Restructuring and Modernisation of Agriculture, pol. Agencja Restrukturyzacji i Modernizacji Rolnictwa, ARiMR) the cadastral data from all geodesic centres in Poland was catalogued and merged into one database. Do not expect geodetic accuracy from it, however, it is a very useful collection for everyone who wants to have an overview of the distribution of parcels; data can only be used for the approximate identification and spatial location of the parcel and for estimating its area. The data is made available for download as ZIP packages containing data in the SHP format, by area division into counties. Figure 3 depicts cadastral data for Braniewo county. 


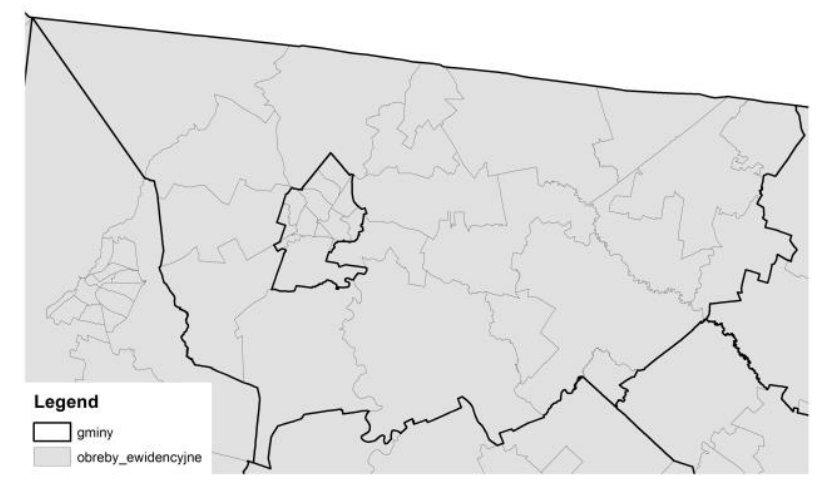

Fig. 2. State register of boundaries and areas of territorial division units of the country (pol. państwowy rejestr granic-PRG), municipalities and registration districts, gugik.gov.pl/pzgik/dane-bez-oplat/dane-z-panstwowego-rejestru-granic-i-powierzchni-jednostekpodzialow-terytorialnych-kraju-prg, 17.07.2018

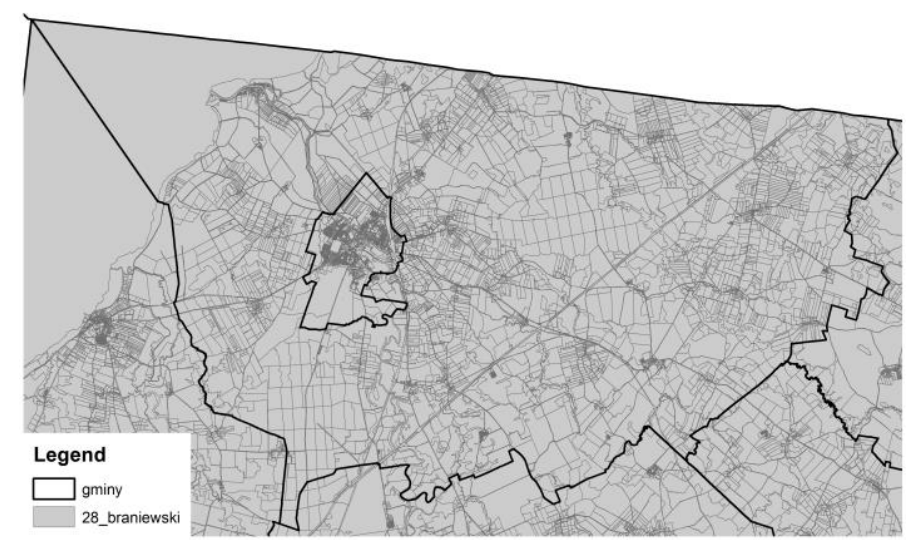

Fig. 3. Cadastral data for Braniewo county, geoportal.gov.pl/web/guest/DOCHK, 17.07.2018

Statistics Poland (pol. Gtówny Urzad Statystyczny, GUS) is the owner of many spatial data (including data covered by the INSPIRE Directive). Geostatistical portal GUS (geo.stat.gov.pl/start) is a solution for presenting statistical data in spatial terms. It fulfils the task of gathering, presenting and sharing information for a wide audience, including public administration, entrepreneurs, individual users and scientific and research institutions. In addition to strictly spatial data, statistical data published at the Local Data Bank (pol. Bank Danych Lokalnych, bdl.stat.gov.pl/BDL/start) may be useful for GIS users. It's possible to download statistical data and combine it with geometric data, for example, with boundaries of territorial division units from CODGiK, to create cartograms. Figure 4 presents statistical data of registered unemployment rate, division into Polish counties.

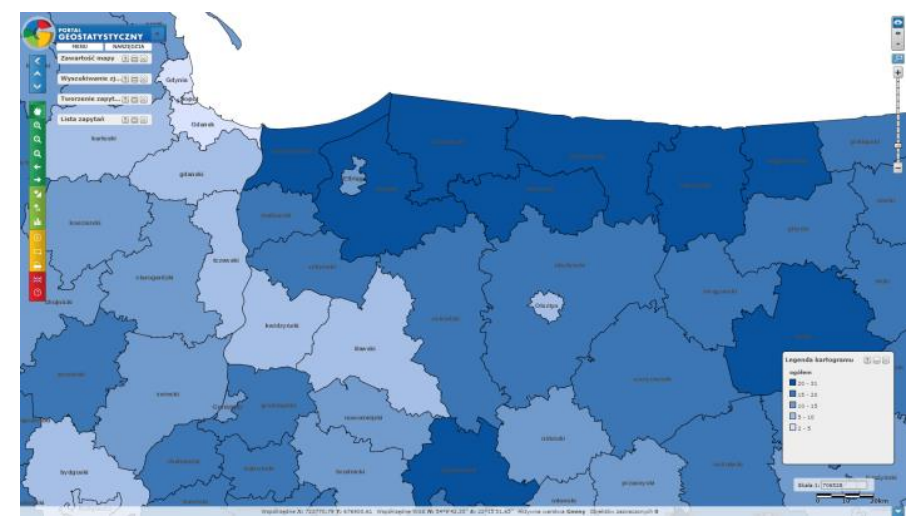

Fig. 4. Registered unemployment rate, division into counties, geo.stat.gov.pl/imap, 17.07.2018 
General Directorate for Environmental Protection (pol. Generalna Dyrekcja Ochrony Środowiska, GDOŚ) is the most reliable source of spatial data about forms of nature protection. GDOŚ provides free of charge data in WMS and SHP formats, containing information about: National parks, Landscape parks, Nature reserves, Protected landscape areas, Special areas of conservation ("habitats" Natura 2000), Special protection areas ("Bird" Natura 2000), landscape-nature complexes, Documentation sites, Ecological areas, Natural monuments (division into counties), RAMSAR Areas, Landscape Convention (mezoregions), Ecological corridors. The GDOŚ Spatial Information System can be found at: geoserwis.gdos.gov.pl/mapy. Figure 5 depicts various forms of nature protection on the example of Braniewo county from GDOŚ Spatial Information System.

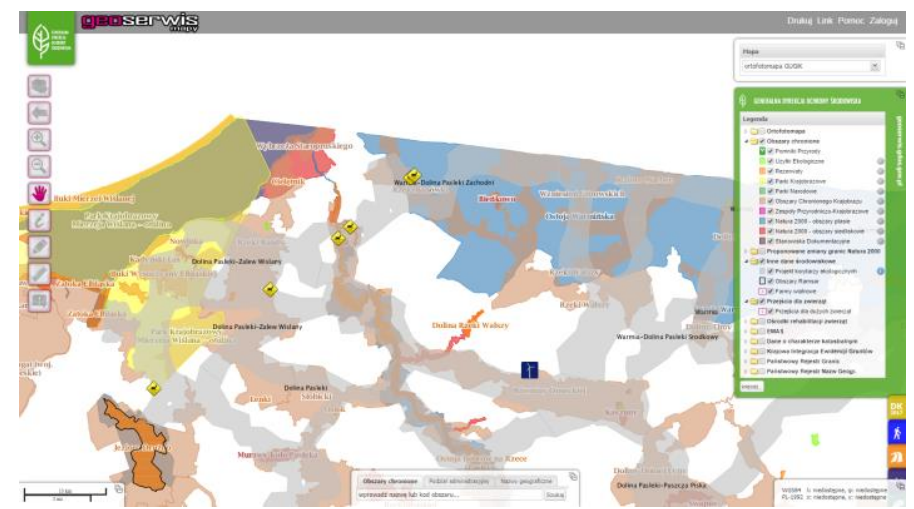

Fig. 5. Various forms of nature protection on the example of Braniewo county, geoserwis.gdos.gov.pl/mapy, 17.07.2018

OpenStreetMap (OSM) is an online community project aimed at creating a free and available map of the entire globe, it is edited by registered users. The creation and development of the OSM was motivated by limitations in the accessibility and use of maps and the emergence of inexpensive portable satellite navigation devices. The data and the maps created on their basis are currently published on the Open Database License. The online service of the German company GEOFABRIK (download.geofabrik.de) collects vector data from around the world, updates it every $24 \mathrm{~h}$, and also allows free of charge download in SHP format. In the GEOFABRIK database, the following vector data (points, polylines and polygons) can be found: buildings, land uses, towns, sacral buildings, historical monuments, sports and recreation facilities, railway lines, roads, water reservoirs and waterways, and many more. Figures 6 and 7 shows OpenStreetMap data from GEOFABRIK service, respectively: landuse; and buildings, railways, roads, traffic information, water and waterways; on the example of Braniewo county.

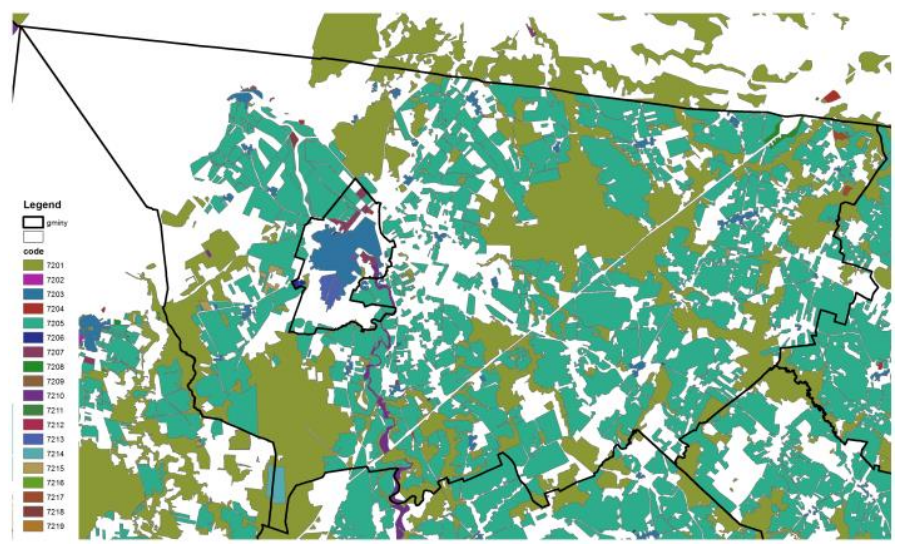

Fig. 6. OpenStreetMap data from GEOFABRIK service, land use on the example of Braniewo county, download.geofabrik.de, 17.07.2018 


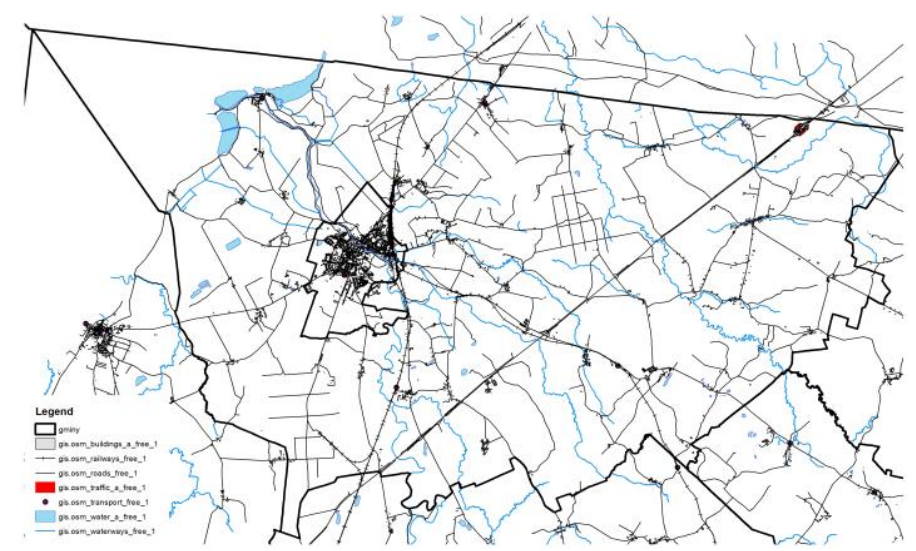

Fig. 7. OpenStreetMap data from GEOFABRIK service; buildings, railways, roads, traffic information, water and waterways; on the example of Braniewo county, download.geofabrik.de,

17.07.2018

DanePubliczne.gov.pl is a website that aims to collect in one place data (not only spatial) of particular importance for the development of innovation in the country and the development of the information society. Data sets can be searched by categories, data providers, keywords and also by entering a search phrase. No registration is required to use the website. The data providers include, among others: government administration; The Polish Social Insurance Institution; The Agricultural Social Insurance Fund; National Health Fund; state research institutes; Polish Academy of Sciences; and scientific units. The duty of the suppliers is to provide data on the website, to frequently update and to ensure availability for download. The website contains data in many formats, e.g. SHP, CSV. Figure 8 presents density of historic monuments, on the example of Braniewo country, from the National Inventory of Historical Monuments.

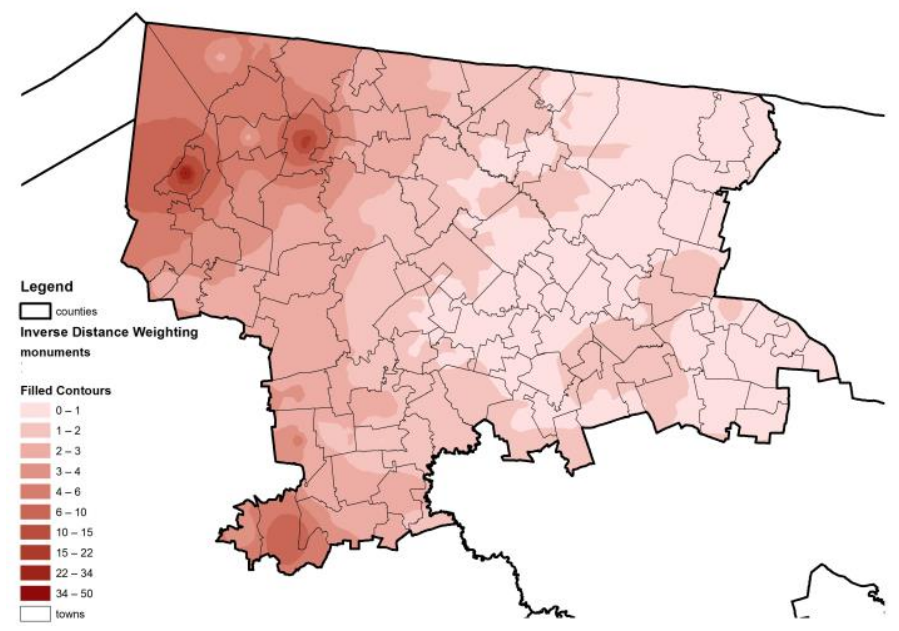

Fig. 8. Density of historic monuments, on the example of Braniewo country, from the National Inventory of Historical Monuments, danepubliczne.gov.pl, 17.07.2018

Sentinel is a series of European space-based remote-sensing missions. Name "Sentinel" covers both proper satellites (e.g. Sentinel-1) and single satellite instruments (e.g. Sentinel-4). Sentinel missions are part of the Copernicus program, initiated and funded by the European Union. Technological supervision over the construction of Sentinel satellites and instruments is carried out by the European Space Agency (ESA). EO Browser (sentinel-hub.com/explore/eobrowser) makes it possible to browse and compare full resolution images from a complete archives of Sentinel-2, Sentinel-3, Sentinel-1, ESA's archive of Landsat 5, 7 and 8, global coverage of Landsat 8, Envisat Meris and Proba-V. The service also allows to analyse the spectrum of light, giving following indicators: NDVI, moisture index, SWIR, NDWI, NDSI; and also allows any colour bands setting. The website gives the 
possibility of downloading free of charge raster data for any place in the world. Figures 9 and 10 shows respectively: moisture index and Normalized Difference Vegetation Index on the example od Braniewo county.

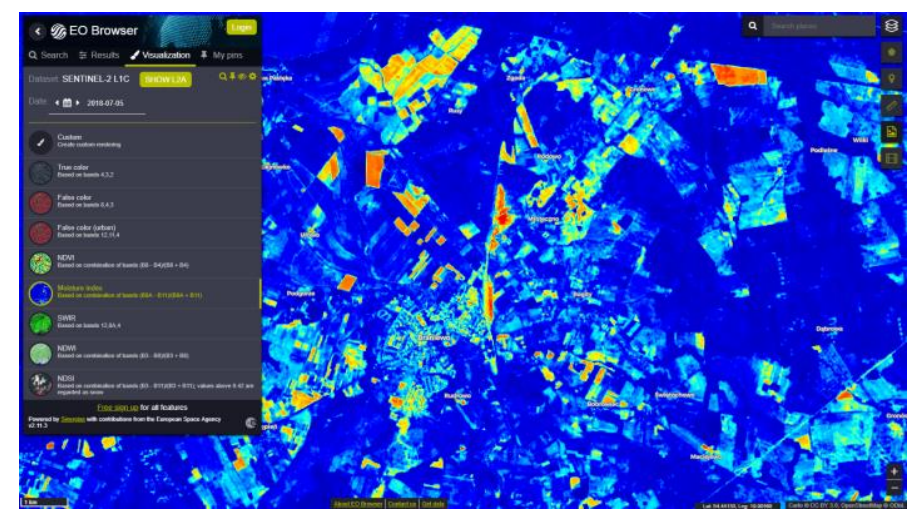

Fig. 9. Moisture index on the example od Braniewo county, sentinel-hub.com/explore/eobrowser, 17.07.2018

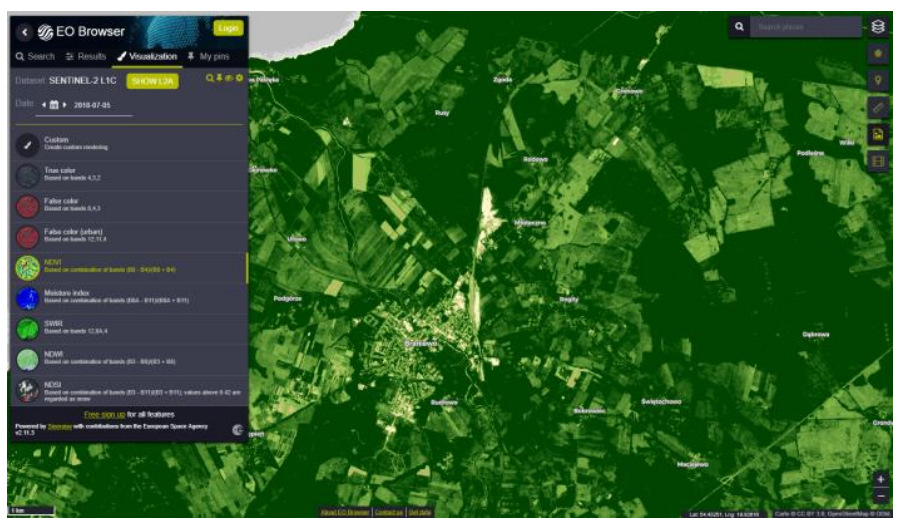

Fig. 10. Normalized Difference Vegetation Index on the example od Braniewo county, sentinel-hub.com/explore/eobrowser, 17.07.2018

The European Environment Agency (EEA) is an agency of the European Union that provides reliable and objective information about the environment. The tasks of the EEA include supporting sustainable development and helping to achieve a significant and visible improvement of the environment in Europe by providing up-to-date, relevant, and reliable data to decision-makers and the public. The EEA website (eea.europa.eu) contains huge amounts of spatial data for EU Member States. The data is divided into a number of topics, e.g. air pollution, land use, water and marine environment, agriculture, energy, industry, transport. There is a possibility of free of charge download of vector and raster data, in many formats. The service also contains many interactive maps. Figure 11 presents fragmentation pressure of urban and transport infrastructure expansion. 


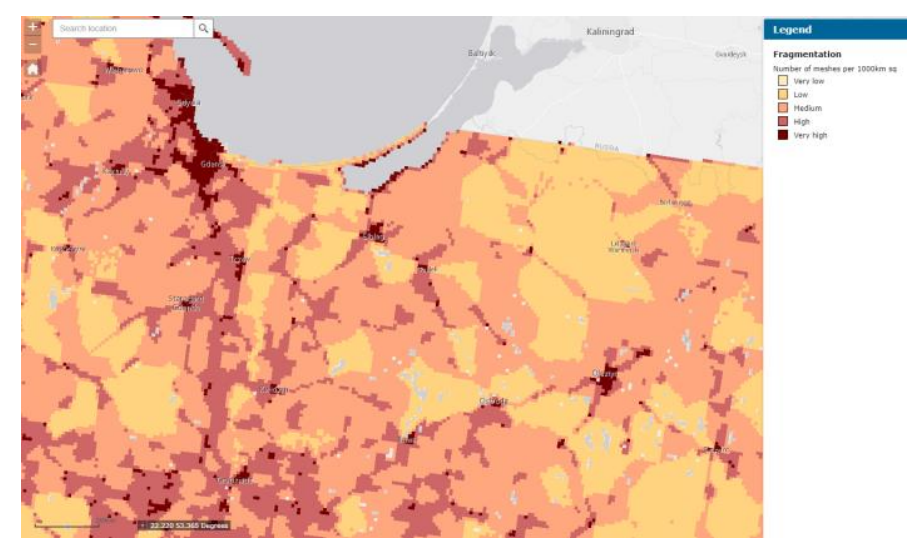

Fig. 11. Fragmentation pressure of urban and transport infrastructure expansion, light colours mean less fragmentation pressure and dark colours mean more fragmentation pressure exerted by urban and transport infrastructure expansion, eea.europa.eu/data-and-maps, 17.07.2018

\section{Conclusions and proposals}

Research carried out in the article allowed to formulate the following conclusions and proposals:

1. For conducting analyses related to revitalization and renewal of the rural areas, detailed spatial location of data is necessary. In existing spatial information systems, the level of accuracy usually ends at the level of territorial division units (most often it is the county or municipality level), while the revitalization and renewal of the rural areas needs point or line data.

2. In order to carry out revitalization and renewal of the rural areas, additional data from local institutions needs to be obtained, e.g.: Municipal Social Welfare Centre, municipal office, municipal police, employment service, environmental protection inspectorate, conservator of monuments, National Support Centre for Agriculture (pol. Krajowy Ośrodek Wsparcia Rolnictwa, KOWR), etc.

3. Spatial data is made available for users free of charge, in convenient and useful formats (e.g. SHP). However, it cannot be directly used in the analyses related to revitalization and renewal of the rural areas. The GIS software (e.g. ArcGIS, QGIS) needs to be used to process data obtained from spatial information systems.

4. In the revitalization and renewal of the rural areas, the participation of the local society is necessary. Activities of renewal of the rural areas require initiation by the residents, therefore, data on their expectations regarding local space should be carried out, for example in the form of: surveys, tests, standardized interviews, debates, public hearings, etc.

5. Some spatial data is mandatory for the revitalization and renewal of the rural areas. This includes: cadastral data (to establish ownership boundaries), boundaries and areas of territorial division units (for localisation of analysed area), forms of nature protection (to define restrictions), various statistical data, and mentioned earlier data from the participation of the local society. All this data needs to be spatially referenced (associated with location), to be the basis for spatial analyses.

6. In order to improve the process of social participation it is advisable to create an online platform for gathering and exchanging opinions of the local community. It is suggested to integrate this platform with GPS mobile devices (e.g. smartphone), which will allow for accurate spatial data placement.

7. The optimal solution for the technical improvement of revitalization and renewal processes would be to create a separate local spatial information system dedicated to the revitalization and renewal of the rural areas. It will be collecting in one place data from the spatial information systems identified in the article and supplemented with local data obtained from other sources mentioned in point 2 (with additional implementation of data obtained as a result of activities related to social participation). Such system would enable comprehensive support for the process of revitalization and renewal of the rural areas. 


\section{Acknowledgments}

This study was developed as part of research grant No. 05/WFKIW/2018 entitled " Preparation of initial assumptions for the creating of the WEB GIS tool for management of the agricultural property of the State Treasury, regarding the needs of renewal and revitalization of the rural areas of the Braniewo county".

\section{References}

1. (Polish) Biczkowski M., Biczkowska M. (2017) Rewitalizacja a odnowa wsi analiza porównawcza instrumentów unii europejskiej. Acta Universitatis Lodziensis Folia Geographica Socio-Oeconomica, No. 29, Łódź, Poland, pp. 27-45

2. (Polish) Cellmer A., Źróbek R. (2008) Informacja przestrzenna w procesach rewitalizacji obszarów miejskich. Acta Scientiarum Polonorum. Administratio Locorum No. 7/4, UWM w Olsztynie, Poland, pp. 5-19.

3. Freire, C. E. de A., \& Painho, M. (2014). Development of a Mobile Mapping Solution for Spatial Data Collection Using Open-Source Technologies. Procedia Technology, 16, 481-490. https://doi.org/10.1016/J.PROTCY.2014.10.115

4. (Polish) Idziak W., Wilczyński R. (2013) Odnowa wsi. Przestrzeń, ludzie, działania. Fundacja Programów Pomocy dla Rolnictwa FAPA. Warszawa, Poland, 160p.

5. (Polish) Kołacz P., Wielgus P. (2015) Przepis na rewitalizację. Fundacja dla Uniwersytetu Kazimierza Wielkiego, Bydgosz, Poland, 78p.

6. (Polish) Narodowe Strategiczne Ramy Odniesienia 2007 - 2013. Wytyczne Ministra Rozwoju Regionalnego w zakresie programowania działań dotyczących mieszkalnictwa. 2008 Warsaw, Poland.

7. (Polish) Rewitalizacja miast: teoria, narzędzia, doświadczenia (2017). Ed. by: Trzepacz P., WarchalskaTroll A., Instytut Rozwoju Miast, Kraków, Poland, 338p.

8. (Polish) Szafraniec M. (2012) Problematyka rozwoju systemów informacyjnych w kontekście zarządzania terenami przekształconymi antropogenicznie. Zeszyty Naukowe Politechniki Śląskiej seria: Organizacja i Zarzadzanie No. 62, Gliwice, Poland, pp. 41-55

9. The administrative Act on Revitalisation of October 9, 2015 (Journal of Laws from 2015, No. 1777)

10. The administrative Act on Geodetic and Cartographic Law of May 17, 1989 (Journal of Laws from 2017, No. 650)

11. Wei, L. Y., Hsu, Y. T., Peng, W. C., \& Lee, W. C. (2014). Indexing spatial data in cloud data managements. Pervasive and Mobile Computing, 15, 48-61. https://doi.org/10.1016/j.pmcj.2013.07.001

12. (Polish) Wilczyński R. (2003) Odnowa wsi perspektywa rozwoju obszarów wiejskich w Polsce. Fundacja Fundusz Współpracy - Program Agro-Info, Krajowe Centrum Doradztwa Rozwoju Rolnictwa i Obszarów Wiejskich Oddział w Poznaniu, Poznań, 168p.

13. (Polish) Wilczyński R. (2008) Programy odnowy wsi w Polsce [in:] Rural Poland 2008. Rural Development Report, Ed. by: Wilkin J., Nurzyńska I. Fundation for the Development of Polish Agriculture. Warsaw, Poland, pp. 99-116

14. (Polish) Wilczyński R. (2012) The Village Renewal with the Use of the European Funds - Untapped Opportunity for Revitalization. Architektura Krajobrazu, Nr 2/2012, vol. 35, Wrocław University of Environmental and Life Sciences, Poland, pp. 4-22

15. Zhao, G., Bryan, B. A., King, D., Song, X., \& Yu, Q. (2012). Parallelization and optimization of spatial analysis for large scale environmental model data assembly. Computers and Electronics in Agriculture, 89, 94-99. https://doi.org/10.1016/J.COMPAG.2012.08.007

\section{Information about authors}

Mateusz Ciski, MSc, assistant and PhD student, University of Warmia and Mazury in Olsztyn, Faculty of Geodesy, Geospatial and Civil Engineering, Institute of Geography and Land Management. Prawochenskiego 15, 10-720 Olsztyn, Poland, tel. +48 895234210, e-mail: mateusz.ciski@uwm.edu.pl . GIS, cartography, geostatistics, historical maps, spatial planning.

Krzysztof Rząsa, PhD, assistant professor, University of Warmia and Mazury in Olsztyn, Faculty of Geodesy, Geospatial and Civil Engineering, Institute of Geography and Land Management. Prawochenskiego 15, 10-720 Olsztyn, Poland, tel. +48 895234210, e-mail: krzysztof.rzasa@uwm.edu.pl . Socio-cultural conditions of spatial management, management of non-urbanized real estate, spatial planning, sustainable development.

Marek Ogryzek, PhD, assistant professor, University of Warmia and Mazury in Olsztyn, Faculty of Geodesy, Geospatial and Civil Engineering, Institute of Geography and Land Management. Prawochenskiego 15, 10-720 Olsztyn, Poland, tel. +48 895234210, e-mail: marek.ogryzek@uwm.edu.pl . GIS, The Agricultural Property Agency, spatial planning, geostatistics, sustainable development. 